\title{
First records of Symphyllophyton campos-portoi Gilg-Ben. (Gentianaceae) in Maranhão and Tocantins states, Brazil
}

\author{
Mauricio Santos da Silva ${ }^{1}$, Dandara Oliveira Sebastião ${ }^{1}$, Laiza Oliveira Silva ${ }^{2}$, Thamires Oliveira \\ Reis $^{3}$, Arthur Filipe Mendes Couto ${ }^{4}$, Abilene Espíndola Correia ${ }^{4}$, Ana Maria Maciel Leite ${ }^{4}$, Raysa \\ Valéria Carvalho Saraiva ${ }^{5}$, Francisca Helena Muniz ${ }^{4}$
}

1 Instituto Nacional de Pesquisas da Amazônia, Programa de Pós-Graduação em Botânica, Av. André Araújo, 2.936, Petrópolis, CEP 69.067-375, Manaus, AM, Brazil. 2 Universidade Estadual do Maranhão, Programa de Pós-Graduação em Recursos Aquáticos e Pesca, Universidade Estadual do Maranhão, Departamento de Biologia, Av. Lourenço Vieira da Silva nº1000, Jardim São Cristóvão, CEP 65055-310, São Luís, MA, Brazil. 3 Museu Paraense Emílio Goeldi, Programa de Pós-Graduação em Botânica, Av. Magalhães Barata, 376 - São Braz, CEP 66040-170, Belém, PA, Brazil. 4 Universidade Estadual do Maranhão, Departamento de Biologia, Av. Lourenço Vieira da Silva n ${ }^{\circ}$ 000, Jardim São Cristóvão, 65055-310, São Luís, MA, Brazil. 5 Universidade Federal do Maranhão, Centro de Ciências Humanas, Naturais, Saúde e Tecnologia, Estrada de Pacas s/n, Enseada, CEP 65200-000, Pinheiro, MA, Brazil.

Corresponding author: Mauricio Santos da Silva, mausantosdasilva@gmail.com

\begin{abstract}
We report the second record of Symphyllophyton campos-portoi Gilg-Ben. in Brazil and the first records from the states of Maranhão and Tocantins, northeastern and northern of Brazil, respectively. The samples were collected in the Cerrado sensu stricto during the beginning of the dry season, within the boundaries of the Parque Estadual do Mirador, Maranhão, and on a farm in northeastern Tocantins. The finding contributes to the knowledge of the flora of these states and expands the known geographic distribution of $S$. campos-portoi. In this work, we present a description of the species, the first photographic record in this environment, and an identification key for the species of Symphyllophyton from Brazil.
\end{abstract}

\section{Keywords}

Brazilian flora, Cerrado, Parque Estadual do Mirador.

Academic editor: Guilherme DS Seger | Received 7 May 2020 | Accepted 18 August 2020 | Published 2 September 2020

Citation: Silva MS, Sebastião DO, Silva LO, Reis TO, Couto AFM, Correia AS, Leite AMM, Saraiva RVC, Muniz FH (2020) First records of Symphyllophyton campos-portoi Gilg-Ben. (Gentianaceae) in Maranhão and Tocantins states, Brazil. Check List 16 (5): 1109-1114. https://doi. org/10.15560/16.5.1109

\section{Introduction}

The family Gentianaceae Juss. comprises 99 genera, with about 1,700 species and seven tribes (Chironieae, Exaceae, Gentianeae, Helieae, Potalieae, Saccifolieae, and Voyrieae), and its distribution is cosmopolitan, except for Antarctica (BFG 2018; Stevens 2020). In Brazil, approximately 123 species and 31 genera (BFG 2018) have been recorded throughout its territory, with 24 species and eight genera recorded from Maranhão, and 12 species and eight genera from Tocantins (Flora do Brasil 2020). This family has its greatest number of species recorded for the phytogeographic domains of Amazon (71) and Cerrado (53) (Flora do Brasil 2020). 
The Chironieae tribe has approximately 23 genera and 160 species with short life cycles that can be annual, biannual or perennial. Their leaves are simple, sessile, rarely petiolate, and with varied shapes; and its representatives may have rosulate phyllotaxis. Based on molecular data, the Chironieae tribe is divided into three subtribes, Chironiinae, Canscorinae, and Coutoubeinae. The Coutoubeinae subtribe has a Neotropical distribution and comprises the genera Deianira Cham. \& Schltdl., Schultesia Mart., Coutoubea Aubl., Symphyllophyton Gilg, and Xestaea Griseb. (Albert and Struwe 2002; Struwe et al. 2002; Delgado et al. 2009). The Coutoubeinae subtribe in Brazil includes four genera (Deianira, Schultesia, Coutoubea, and Symphyllophyton) and 31 species, with records of 13 species from Maranhão and eight species from Tocantins.

The genus Symphyllophyton Gilg is endemic to Brazil. Only two species have been described, S. caprifolioides Gilg and S. campos-portoi Gilg-Ben., with their distribution in the states of Maranhão, Piauí, Bahia, Tocantins and Goiás (Siqueira et al. 2014; Flora do Brazil 2020). Symphyllophyton caprifolioides is recorded in the Cerrado and Caatinga domains, and $S$. campos-portoi is recorded only in the Caatinga (Flora do Brazil 2020).

This genus differs from the other genera of the tribe in having a stipitate ovary, and to other genera in the subtribe Coutoubeinae by exhibiting unequal stamens. The species of the genus are herbs, with green branches, cylindrical rather than square in cross-section, solid, and glabrous. The leaves are green, sessile, opposite, broadelliptical, darker green adaxially than abaxially, leathery, and glabrous. The flowers are tetramerous (four sepals and four petals), disposed in diffuse, terminal, and pedicellate dichasia. The calyx is green, funnelform to urceolate, carinate but not winged, and glabrous. The corolla is salverform, white or cream-colored with a rose-purple and yellow center, or completely rose-purple; the corolla tube is about as long as the lobes; the stamens are inserted below the middle of the corolla tube, two with longer filaments and larger anthers alternating with two smaller stamens, all fertile; the connective is prolonged; the ovary is unilocular; the style is slender and caducous; the nectaries are located at the base of the ovary. The fruit capsule is septicidal (Siqueira et al. 2014; Struwe and Pringle 2018).

The distribution of Symphyllophyton campos-portoi is restricted to its type locality in Piauí (Gilg 1936). Here we report the first records of this species in the states of Maranhão and Tocantins.

\section{Methods}

Study region. The collection of the botanical material was carried out at the Parque Estadual do Mirador (PEM), Maranhão, Brazil (Fig. 1), in August and November 2017. The required legal permit was granted and issued by the Secretaria de Estado do Meio Ambiente e Recursos Naturais (SEMA; n 194229/2014).
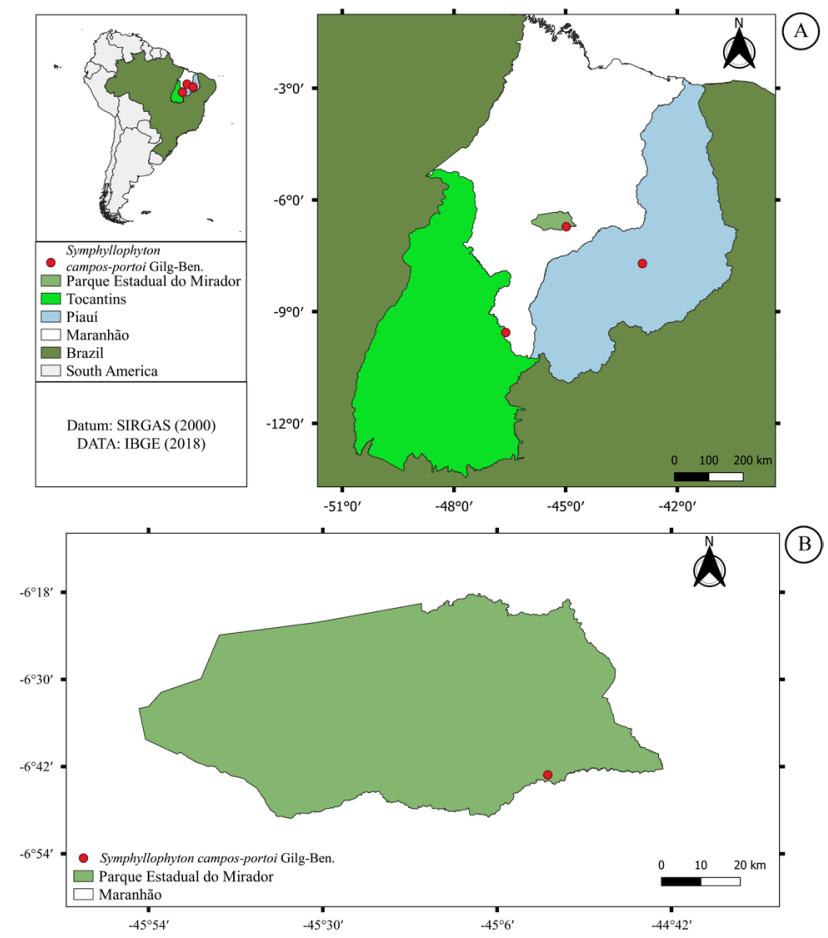

Figure 1. Occurrence map of Symphyllophyton campos-portoi GilgBen. species (A) in Brazil; and (B) in the Parque Estadual do Mirador, Maranhão, Brazil.

The PEM is located in the center-meridional region of the state of Maranhão (between $06^{\circ} 10^{\prime} \mathrm{S}, 044^{\circ} 43^{\prime} \mathrm{W}$ and $06^{\circ} 42^{\prime} \mathrm{S}, 045^{\circ} 54^{\prime} \mathrm{W}$; $425 \mathrm{~m}$ asl.), between the headwaters of the Itapecuru and the Alpercartas rivers, and encompasses the municipalities of Mirador, Formosa da Serra Negra and Fernando Falcão. Created in 1980 by the State Decree $n^{\circ} 641$ of June 20, PEM has the Cerrado sensu lato as the predominant vegetation (Fig. 2) (Da Conceição and Castro 2009), with red-yellow latosols associated with quartz sands and lithic, stony, and rocky soils. The PEM area was expanded by the Law $\mathrm{n}^{\circ}$ 8.958 of May 8, 2009, now having a total area of 766,781 ha (Maranhão 2009). According to the Köppen climate classification, the climate is of Aw type (dry sub-humid tropical), with annual rainfall of 1,200-1,400 $\mathrm{mm}$, and

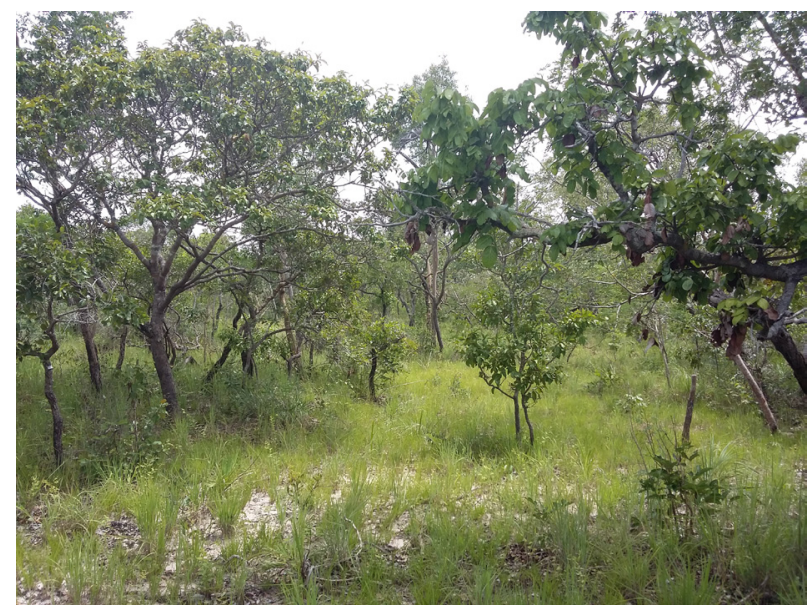

Figure 2. Vegetation of the Parque Estadual do Mirador, Maranhão, Brazil. 
average temperatures ranging from $19.5^{\circ} \mathrm{C}$ to $33^{\circ} \mathrm{C}$ (Alcântara 2004; Andrade et al. 2017).

The collection site in Tocantins, in turn, is located in the northeastern region of the state, on the right margin of an unpaved road (at Itagi farm, in a Cerrado sensu stricto region) that connects the municipalities of Lizarda (Tocantins state) and Alto Parnaíba (Maranhão state) and presents a distance of $542 \mathrm{~km}$ from the PEM, through road BR-230 and MA-006.

Data collection. This work is part of the Rede ComCerrado Project, which aims to collect phytosociological data on the herbaceous-subshrub vegetation of the Cerrado sensu stricto phytophysiognomy. The fieldwork in the PEM included 10 plots equally distributed along two $5 \mathrm{~km}$ trails, each plot measuring $500 \mathrm{~km}^{2}$. The collection of fertile individuals of the species recorded here (Fig. 3) was carried out in the plot 2 of the trail 2. It was used the standard method for herbarium preparation. The collected material was sent to the laboratory for dehydration procedures at hot air oven conditions. Then, it was deposited in the collection of the Rosa Mochel-SLUI Herbarium, Universidade Estadual do Maranhão, Brazil.

The identification was performed according to the taxonomic treatments for genus and family (Siqueira et al. 2014; Struwe and Pringle 2018), by comparing them with the specimens available at the Herbarium of the Botanical Garden of Rio de Janeiro (RB) and Herbarium of the State University of Tocantins (HUTO), botanical sites: Flora do Brasil (2020), Tropicos (2020), speciesLink (2020), and expert consultations. The individuals from Tocantins, collected in 2016, were found after examining online the material of HUTO. We used a Zeiss Stemi dv4 stereo microscope for viewing the characteristics of the plant. Photographic documentation was done with the aid of a Nikon D5300 camera. Map was created using the Free and Open Source QGIS v. 3.4 (QGIS 2020). The preliminary conservation status of the species was based on the International Union for Conservation of Nature Red List criteria and guidelines (IUCN 2019).

\section{Results}

Symphyllophyton campos-portoi Gilg-Ben., 1936; Notizblatt des Königl. botanischen Gartens und Museums zu Berlin-Dahlem 13 (118): 381-383.

Figure 4

New records. BRAZIL • Maranhão, Parque Estadual do Mirador, Posto do Mel; 06²3'20.70"S, 04459'35.51"W; 10 Aug. 2017, M.S. Silva et al. 100 col.; plot 2, trail 2; SLUI 5000. - Tocantins, Lizarda Road, 09³3'40.00"S, 046³6'36.00"W), 12 Aug. 2016; E.R. Santos 2385 leg.; HUTO 6416.

Additional material examined. BRAZIL • Maranhão, Parque Estadual do Mirador, Mirador; 06²3'33.40"S, 044²8'36.71"W; Nov. 1989; fl.; F. Noberto 187 col.; SLUI 449 [exsiccate]. - Piauí, Puça Agreste, 07²2'31.205"S, 042 56'18.618"W; 06 Aug. 1912; fl.; photographed by P. Luetzelburg 1204-1208; RB 5926 [photo]. - Tocantins, Fazenda Itagi, on the right margin of the Lizarda road; 09³3'37.001"S, 046³6'36.000"W; 12 Aug. 2016; fl.; E.R. Santos 2384 col.; HUTO 6415 [photo].
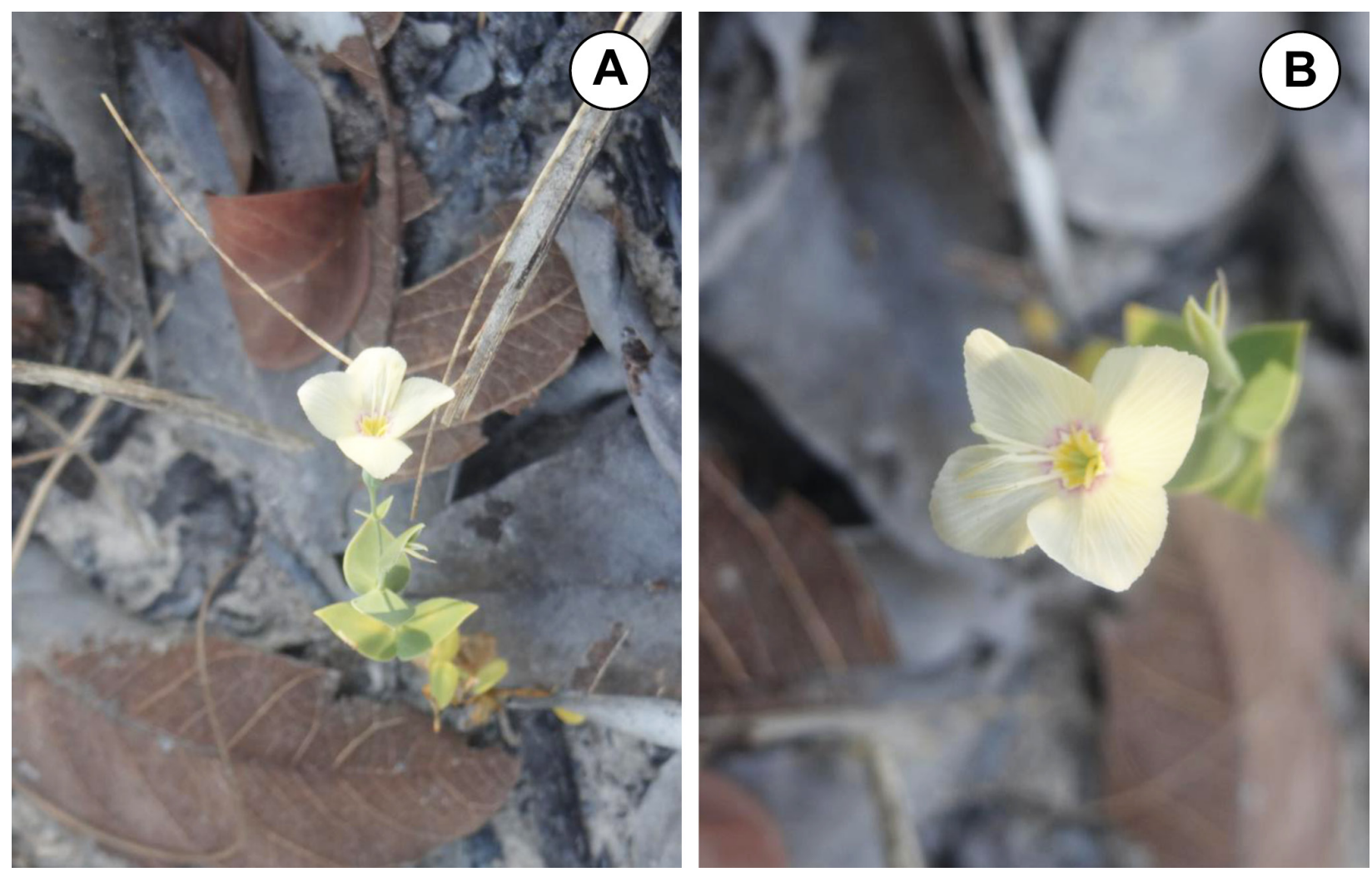

Figure 3. Plant of Symphyllophyton campos-portoi Gilg-Ben. A. Plant in its habitat. B. Detail of the flower. 


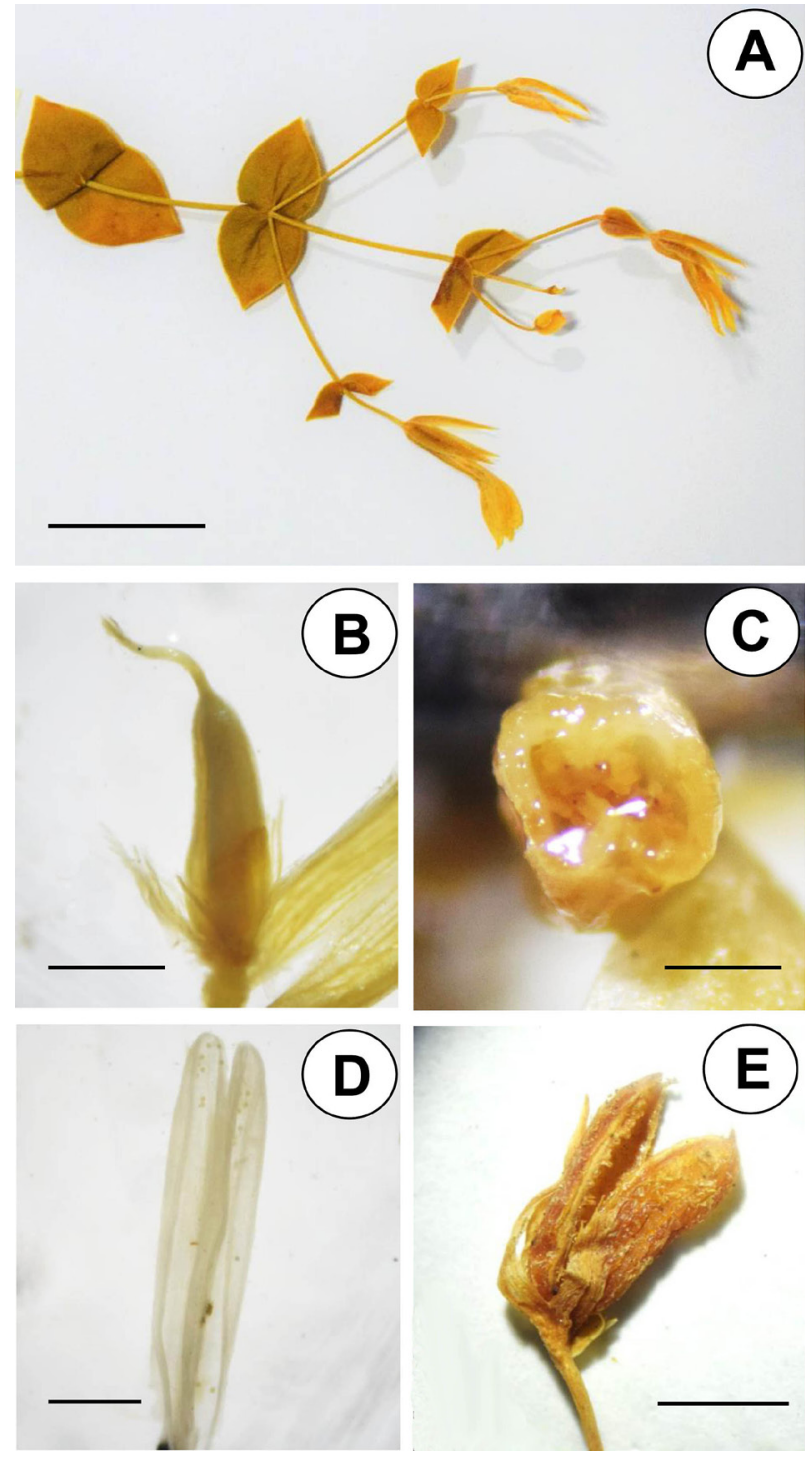

Figure 4. Symphyllophyton campos-portoi Gilg-Ben. A. Herborized plant detail (SLUI 5000). B. Ovary in longitudinal view. C. Crosssection of the ovary. D. Anther. E. Open fruit. Scale bars: $A=2.0$ $\mathrm{cm} ; \mathrm{B}=0.2 \mathrm{~cm} ; \mathrm{C}, \mathrm{D}=0.1 \mathrm{~cm} ; \mathrm{E}=0.4 \mathrm{~cm}$.

Habitat. Caatinga (Gilg 1936) and Cerrado (this work).

Distribution. Piauí (Gilg 1936), Maranhão and Tocantins (this work).

Preliminary conservation status. We assessed this species as Endangered (criteria EN) according to B1 (EOO $\left.<5000 \mathrm{~km}^{2}\right)$ and $\mathrm{B} 2 \mathrm{ab}$ (ii, iii) $\left(\mathrm{AOO}<500 \mathrm{~km}^{2}\right)$ from IUCN (2019). This species is threatened due to the existence of records of individuals from fragmented and small populations in protected areas or in private properties. The suitable habitat of the species is in decline due to the progression of Brazilian agricultural projects in Cerrado areas in the states of Maranhão, Piauí and Tocantins (Sano et al. 2008).

Description. Herb $13.5-24.5 \mathrm{~cm}$ in height, leaves 1.0 $1.1 \times 0.9-1.0 \mathrm{~cm}$, elliptic to obovate, opposite with a non-connate base, margin continuous, stipules absent; inflorescences cymes, lax; flowers $1.3-1.6 \times 0.3 \mathrm{~cm}$, pedicels $0.5-0.7 \mathrm{~cm}$, bisexual, actinomorphic, tetramerous; calyx $1.0 \times 0.1 \mathrm{~cm}(4)$, green, gamosepalous; corolla (4), white with lilac and yellow details in the center, gamopetalous, salverform, flower buds convolute, stamens 0.4 $\times 0.1 \mathrm{~cm}$, epipetalous (3) inserted near the corolla base, with reniform anthers (longitudinally dehiscent), ovary $0.3 \times 0.1 \mathrm{~cm}$, superior, bicarpellate, unilocular, with parietal placentation, pluriovulate, single style $0.1-0.2 \mathrm{~cm}$ long, with thin papillae in the stigma. The fruit is a capsule of $0.7 \times 0.3-0.4 \mathrm{~cm}$.

\section{Identification key to the species of Symphyllophyton from Brazil}

1. Leaves long-elliptic with a connate base S. caprifolioides Gilg

1'. Leaves elliptic to obovate, with a non-connate base S. campos-portoi Gilg-Ben.

\section{Discussion}

Symphyllophyton campos-portoi was described in 1935 by Charlotte Gilg based on a material from the state of Piauí, collected in 1912 by V. Lützelburg, and deposited in the Herbarium of the Botanical Garden of Rio de Janeiro (RB 5926) (Guimarães 1966). Since then, no other records have been published. The material collected in the Parque Estadual do Mirador, in the state of Maranhão, and on a farm of Tocantins, are the first records after the original description, and also the first from both states. Additionally, the previous known record was in an area of Caatinga (Flora do Brasil 2020) and our material was collected in areas of Cerrado sensu stricto. Thus, we report the occurrence of this rare species to contribute to the knowledge of the local flora.

Along the $10 \mathrm{~km}$ fieldwork in PEM, we found the species $S$. campos-portoi only in a single plot of the sampling area, with a small population of six individuals. To guarantee the success of the species in its environment, in the first collection (August 2017), we sampled only three individuals. In November 2017, we found the same population at the previously sampled plot and collected two more individuals, recording a total of seven individuals in November with dry (dead) parts (dry flowers).

The collection locality from the state of Piaui is not part of any conservation unit and, until the present study, the species $S$. compos-porto $i$ was restricted to this region. The same situation is observed for the record in the state of Tocantins, in the Fazenda Itagi, municipality of Lizarda. Only the record found at the PEM is included in a conservation unit, so it is important to emphasize that the three states are a part of the deforestation arc. Thus, the permanence and preservation of the PEM is extremely important for the conservation of this species, besides its importance for biodiversity protection, and ecosystem processes and services (Colli-Silva et al. 2019).

Furthermore, studies on the flora of Maranhão at PEM have found new records for the state (Saraiva et al 2020; Silva et al 2020), which is still botanically undersampled. One of the major problems in determining 
species distribution and endemism patterns is related to the poor knowledge on the distribution limits of the known species. Despite the importance of advancing research in this ambit, without knowledge on the species, which is one of the biggest gaps in Piauí, Maranhão, and Tocantins (Boubli and Hrbek 2012), conservation projects are rather destined to better known areas (with greater aggregated value) than to regions which possess greater biological value (Knapp 2002).

The flowering period for the species is still uncertain, but with the field observations and data made available by the herbaria, it can be inferred that the species flowers in the months of August to the end of October and bears its fruit in the month of September and October (a record for the species was found in the SLUI herbarium, F. Noberto 187, with incorrect identification showing flowers and fruits, with collection date in September 1989 for PEM). The plant was found close to individuals of Trachypogon spicatus (L. F.) Kuntze in more shaded areas, protected by the canopy cover of some tree species and it was seen a larger amount of dead trunks and organic matter than in other nearby areas.

The Gentianaceae family is relatively well represented in the Cerrado, mainly in areas with more humid soil and in open fields (Souza et al. 2018). In the state of Maranhão, Gentianaceae is still poorly sampled and many species are yet to be recorded, as was done by Ferreira et al. (2018) that recorded the species Voyria caerulea Aubl. for the first time in São Raimundo das Mangabeiras, a municipality located close to PEM. Therefore, a greater effort of collection and identification is required, which can be achieved through floristic survey projects for the region.

\section{Acknowledgements}

We thank the State University of Maranhão for assistance in the field trips and the Herbário Rosa Mochel for the support in the development of the work. Maranhão Research Foundation (FAPEMA) and Rede ComCerrado for financing the project. To the Herbarium of the Botanical Garden of Rio de Janeiro and the Herbarium of the State University of Tocantins for the online supply of the studied exsiccatae. And to the reviewers, Maria Neves Delgado, James Pringle, and an anonymous reviewer for contributing to improve the text.

\section{Authors' Contributions}

MSS, LOS, TOR, AFMC, ACE and FHM collected and photographed the plant in the environment. MSS, TOR, FHM, RVCS and AMML revised the herbarium collections. MSS and RVCS identified the specimen and photographed it in the herbarium. MSS, RVCS and FHM wrote the text. AFMC, ACE, LOS, DOS and FHM revised the text.

\section{References}

Albert VA, Struwe L (2002) Gentianaceae in context. In: Struwe L, Albert VA (Eds) Gentianaceae: systematics and natural history. Cambridge University Press, Cambridge, 1-10.

Alcântara EH (2004) Caracterização da bacia hidrográfica do rio Itapecuru, Maranhão - Brasil. Caminhos de Geografia 7 (11): $97-$ 113.

Andrade EB, Weber LN, Leite JRSA (2017) Anurans of the Parque Estadual do Mirador, a remnant of Cerrado in the state of Maranhão, northeastern Brazil. Biota Neotropica 17 (4): 1-12. https:// doi.org/10.1590/1676-0611-bn-2016-0260

BFG, The Brazil Flora Group (2018) Brazilian Flora 2020: innovation and collaboration to meet Target 1 of the Global Strategy for Plant Conservation (GSPC). Rodriguésia 69 (4): 1513-1527. https://doi. org/10.1590/2175-7860201869402

Boubli JP, Hrbek T (2012) Introdução à biodiversidade amazônica. In: Marcon JL, Menin M, Araújo MGP, Hrbek T (Eds) Biodiversidade Amazônica: caracterização, ecologia e conservação. Edua, Manaus, 11-17.

Colli-Silva M, Ivanauskas NM, Souza FM (2019) Diagnóstico do conhecimento da biodiversidade de plantas vasculares nas unidades de conservação do estado de São Paulo. Rodriguésia 70: 1-11. https://doi.org/10.1590/2175-7860201970068

Da Conceição GM, Castro AAJF (2009) Fitossociologia de uma área de cerrado marginal, Parque Estadual do Mirador, Mirador, Maranhão. Scientia Plena 5 (10): 1-16.

Delgado MN, Azevedo AA, Valente GE, Kasuya MCM (2009) Morfoanatomia comparada de espécies da subtribo Coutoubeinae (Chironieae - Gentianaceae). Acta Botanica Brasilica 23 (4): 956-967.

Ferreira AWC, Calió MF, Silva-Júnior WR, Silva MJC, Oliveira MS, Silva EO, Guarçoni EAE, Carvalho AKC, Figueiredo N (2018) First record of Voyria caerulea Aubl. (Gentianaceae), a mycoheterotrophic plant, in Maranhão state, northeastern Brazil. Check List 14 (5): 833-837. https://doi.org/10.15560/14.5.833

Flora do Brasil (2020) Jardim Botânico do Rio de Janeiro. http:// floradobrasil.jbrj.gov.br/. Accessed on: 2020-4-19.

Gilg C (1936) Neue Gentianaceen aus Südamerika. Notizblatt des Königl. botanischen Gartens und Museums zu Berlin-Dahlem 13 (118): 381-383. https://doi.org/10.2307/3995015

Guimarães FE (1966) Typus do herbário do Jardim Botânico do Rio de Janeiro IV. Rodriguésia 25 (4): 265-295.

IUCN (2019) Guidelines for using the IUCN Red List categories and criteria. Version 14. Prepared by the Standards and Petitions Committee. http://www.iucnredlist.org/documents/RedListGuidelines.pdf. Accessed on: 2020-5-11.

Knapp S (2002) Assessing patterns of plant endemism in Neotropical uplands. The Botanical Review 68 (1): 22-37.

Maranhão (2009) Lei n $^{\mathrm{o}} 8.958$ de 08 de maio de 2009. Altera o Decreto $n^{\circ} 7.641 / 80$ de junho de 1980, que cria o Parque Estadual de Mirador e dá outras providências.: Diário Oficial do Estado, São Luís, 3 pp.

QGIS (2020). Sistema de Informação Geográfica QGIS. Projeto Open Source Geospatial Foundation. http://www.qgis.org. Accessed on: 2020-3-17.

Sano EE, Rosa R, Brito JLS, Ferreira LG (2008) Mapeamento semidetalhado do uso da terra do Bioma Cerrado. Pesquisa Agropecuária Brasileira 43 (1): 153-156. https://doi.org/10.1590/S0100204X2008000100020

Saraiva RVC, Leonel LV, Reis FF, Figueiredo FAMMA, Reis FO, Sousa JRP, Muniz FH, Ferraz TM (2020) Cerrado physiognomies in Chapada das Mesas National Park (Maranhão, Brazil) revealed by patterns of floristic similarity and relationships in a transition zone. Anais da Academia Brasileira de Ciências 92 (2): 1-16. https://doi.org/10.1590/0001-3765202020181109

Silva MS, Reis TO, Silva LO, Couto AFM, Correia AE, Leite AM, Saraiva, RVC, Muniz FH (2020) Fitossociologia do estrato her- 
báceo-subarbustivo do Parque Estadual do Mirador, Maranhão, Brasil. Brazilian Journal of Development 6 (5): 26435-26449. https://oi.org/10.34117/bjdv6n5-192

Siqueira GB, Santo FSE, Rapini A (2014) Flora da Bahia: Gentianaceae. Sitientibus série Ciências Biológicas 14: 1-35. https://doi. org/10.13102/scb295

Souza VC, Flores TB, Colletta GD, Coelho RLG (2018) Guia das plantas do Cerrado. Taxon Brasil Editora e Livraria, Piracicaba, São Paulo, $584 \mathrm{pp}$

speciesLink (2020) http://www.splink.org.br. Accessed on: 2020-3-17.

Stevens PF (2020) Angiosperm phylogeny website. http://www.mo bot.org/MOBOT/research/APweb/. Accessed on: 2020-3-16.
Struwe L, Pringle JS (2018) Gentianaceae. In: Kadereit JW, Bittrich V (Eds) Flowering Plants. Eudicots. The families and genera of Vascular Plants, vol. 15. Springer, Cham, 453-503. https://doi. org/10.1007/978-3-319-93605-5 6

Struwe L, Kadereit JW, Klackenberg J, Nilsson S, Thiv M, Von-Hagen KB, Albert VA (2002) Systematics, character evolution, and biogeography of Gentianaceae, including a new tribal and subtribal classification. In: Struwe L, Albert VA (Eds) Gentianaceae: Systematics and Natural History. Cambridge University Press, Cambridge, 21-209. https://doi.org/10.1017/CBO9780511541865.003

Tropicos (2020) Missouri Botanical Garden. http://www.tropicos.org/ Name/13801984. Accessed on: 2019-4-19. 